\title{
Pelatihan Desain Media Pembelajaran Berorientasi Keterampilan Berpikir Kritis dan Kreatif Bagi Guru SD SN Najwa Rengas Pulau Kecamatan Medan Marelan
}

\author{
Yusmar Ali*, Faudunasokhi Telaumbanua, Siti Aisyah \\ Program Studi Teknik Grafika, Politeknik Negeri Media Kreatif, Medan, Indonesia \\ Email: 1,*Yusmaralimmsi@gmail.com,
}

\begin{abstract}
Abstrak-Pandemi covid-19 memberikan dampak bukan hanya sektor industri tetapi juga sektor pendidikan. Mitra Pengabdian kepada Masyarakat Kompetitif ini adalah kelompok Guru SD An Najwa. SD An Najwa berlokasi di kelurahan Rengas Pulau kecamatan Medan Marelan. Sekolah ini memiliki 10 orang Guru dan 60 orang siswa. Selama pandemi, sekolah menjalankan kebijakan proses belajar secara tatap muka dan bergantian, hal ini dikarenakan para Guru tidak mempunyai kemampuan dalam mendesain media pembelajaran kreatif untuk belajar secara daring. Namun demikian, kualitas belajar siswa tetap menurun karena durasi belajar yang pendek. Sehinggapermasalahan yang dihadapi mitra adalah sumber daya guru yang tidak memiliki kemampuan dibidang penggunaan teknologi dan informasi khususnya desain media pembelajaran, membuat menurunnya kualitas dan minat belajar siswa. Solusi yang ditawarkan adalah memberikan pelatihan desain bahan ajar, memberikan pelatihan membuat video ajar, dan memberikan pelatihan membuat evaluasi proses pembelajaran. Metode dilaksanakan dengan cara pemberian ceramah dan praktek, dengan tiap 1 jenis pelatihan dilakukan $4 \mathrm{x} 2$ jam pertemuan selama 1 bulan. Melalui pengabdian kepada masyarakat ini para guru meningkatnya pengetahuan, keterampilan dan kreatifitas mitra serta peningkatan capaian pembelajaran siswa yang dinilai dari hasil belajar.
\end{abstract}

Kata Kunci: Pendidikan; Pembelajaran Kreatif; Teknologi Informasi; Kualitas Belajar; Berfikir Kritis

\begin{abstract}
Pandemic covid-19 impact not only the industrial sector but also the education sector .Partner devotion to the competitive it is a primary school teacher s najwa .Located at the primary school s najwa rengas marelan island in medan .This school has 6010 teachers and students .For pandemics, policy learning in schools run face to face and turns , it was because the teachers do not have the capacity to media in designing creative learning for learning online .However , the quality of students continue to decline because of the short duration of study .Sehinggapermasalahan faced partner is human resources teachers who do not have the ability in terms of the use of technology and information especially design learning media , make the decreasing quality of student learning and interest The solution offered is giving training, teaching materials and design provide training to make video, ajar and provide training to make the evaluation of the learning process.A method to be implemented with the way of making speeches and practice of, with every 1 kind of training conducted $4 \times 2$ hours meeting for 1 months. Through devotion for the public was teachers knowledge, the skill and partner and improve learning from these students discerned from learning outcomes.
\end{abstract}

Keywords: Creative Learning Education; Information Technology; Quality Learn Critical Thinking

\section{PENDAHULUAN}

Munculnya wabah Covid-19 menjadikan dunia pendidikan mencari sebuah inovasi untuk proses kegiatan belajar mengajar. Berdasarkan Surat Edaran Menteri Pendidikan dan Kebudayaan Nomor 4 Tahun 2020 tentang Pelaksanaan Kebijakan Pendidikan dalam Masa Darurat Penyebaran Covid-19, menghimbau agar seluruh kegiatan di institusi pendidikan harus dilakukan dengan menjaga jarak dan penyampaian materi disampaikan dari rumah. Sehingga setiap institusi dituntut memberikan inovasi terbaru untuk proses pembelajaran yang efektif. Walaupun kebijakan belajar dari rumah sudah diberikan kelonggaran, namun tetap saja proses pembelajaran efektif, kreatif dan inovatif harus dihasilkan oleh tenaga pendidik agar dapat menghasilkan siswa yang kritis, kreatif dan kompeten. Walaupun pemerintah sudah mengeluarkan izin untuk sekolah tatap muka dimulai bulan Juli, namun Guru tetap harus bersiap sedia dalam menyediakan media pembelajaran dan bahan ajar yang kreatif dan dapat digunakan secara daring maupun tatap muka. Solusinya guru diminta untuk menyusun media pembelajaran yang inovatif dengan memanfaatkan media daring.

Namun, berdasarkan informasi yang dikumpulkan pra pengabdian, diperoleh bahwa terdapat $85 \%$ dari 20 orangtua mahasiswa komplen terkait proses pembelajaran secara online, karena orang tua tidak mampu mengajarkan anak selayaknya seperti guru di sekolah. Selain itu, menunjukkan juga bahwa hanya 5\% dari 15 guru yang mampu menggunakan teknologi dalam pembelajaran di Kecamatan Medan Marelan. Media pembelajaran dalam proses belajar dan mengajar menjadi satu kesatuan yang tidak dapat dipisahkan dari dunia pendidikan (Tafanao, 2018).

Media pembelajaran digunakan untuk menyalurkan pesan dari dosen kepada mahasiswa, sehingga dapat merangsang perasaan dan pikiran, perhatian serta minat peserta didik untuk belajar. Media pembelajaran yang menarik dapatmeningkatkan motivasi siswa untuk belajar. Peran pembelajar adalah menyediakan, menunjukkan, membimbing dan memotivasi para pembelajar agar dapat berinteraksi dengan berbagai sumber belajar(Falahudin, 2014). Terdapat tiga peran media belajar yaitu agar siswa menangkap peajaran dengan baik, menbangkitkan keinginan belajar, memperjelas penyajian materi dan kemampuan menampilkan objek kembali (Putra, 2015). SD An Najwa merupakan sebuah Sekolah Dasar yang berada di Kelurahan Rengas Pulau, 
Kecamatan Medan Marelan (Gambar 1). Sekolah ini memiliki siswa sebanyak 157 orang dari kelas I sampai kelas VI. Pembelajaran, kompetensi, media pembelajaran, sarana penunjang dan fasilitas layanan sekolah dan disiplin sumberdaya manusia yang ada merupakan faktor - faktor yang yang mempengaruhi pelaksanaan pembelajaran di sekolah.

Berdasarkan pra pengabdian dan hasil diskusi dengan Kepala Sekolah SD An Najwa, bahwa Guru tidak dapat beradaptasi dengan kemajuan teknologi sehingga proses pembelajaran masih dilakukan secara konvensional. Hal ini karena Guru tidak pernah mendapatkan pelatihan terkait penggunaan teknologi dalam pembelajaran. Sehingga, selama pandemi sekolah mengalami kesulitan dalam melakukan pembelajaran dari rumah. Untuk itu, sekolah tetap menjalankan proses pembelajaran secara tatap muka dan bergelombang (kelas I s.d III masuk jam 7.15 - 9.30, kelas IV, V dan VI masuk jam 10.00 - 12.30). Kebijakan ini terpaksa dijalankan pihak sekolah agar proses belajar tetap terlaksana. Melalui diskusi awal dengan mitra, diidentifikasi bahwa pembelajaran SD yang esesnsial yang dapat diajarkan lebih mudah dengan menggunakan media pembelajaran yang interaktif berbasis teknologi. Permasalahan yang terjadi adalah (a) Guru tidak mampu mendesain bahan ajar yang berorientasi pemikiran kritis dan kreatif, selama ini para Guru terbiasa melakukan pembelajaran dengan metode konvensional yang tidak menarik sehingga siswa tidak minat untuk memperhatikan pelajaran. (b) Guru tidak memiliki kemampuan dalam membuat video ajar, durasi pembelajaran yang pendek selama pandemi Covid-19membuat siswa kesulitan dalam memahami pelajaran. Selain itu, ketidakmampuan Guru dalam membuat video ajar membuat kesulitan bagi Guru dan siswa dalam menerapkan Pembelajaran Berorientasi pada Keterampilan Berpikir Tingkat Tinggi seperti yang telah distandarkan oleh Pemerintah. (c) Guru tidak mampu menyusun evaluasi pembelajaran siswa berbasis informasi teknologi agar siswa dapat berpikir kritis dan kreatif. Selama ini, evaluasi pembelajaran dilakukan dengan cara memberikan pertanyaan dan meminta siswa menjelaskan sebuah konsep. Metode ini hanya dapat menilai pemahaman siswa terhadap dasar pelajaran, namun tidak dapat menilai kemampuan pemikiran kritis dan kreatif siswa. Sehingga sangat diperlukan sebuah media evaluasi berbasis teknologi informasi yang dapat membantu Guru dalam menilai kemampuan siswa.

Permasalahan diatas disebabkan guru - guru tidak mempunyai kemampuan dalam mendesain media pembelajaran, video ajar dan bahan ajar untuk mendukung pembelajaran yang lebih efektif. Adapun tujuan dari Pengabdian kepada Masyarakat Kompetitif ini adalah membantu para Guru SD An Najwa dalam mendesain media pembelajaran, membuat video ajar, dan bahan ajar yang berorientasi pada keterampilan berpikir kritis dan kreatif. Dari analisis situasi dan permasalahan yang dihadapi oleh dosen, mitra sebagai pelaksana kegiatan yang dibantu oleh mahasiswa sebanyak 2 orang sebagai tenaga profesional dari perguruan tinggi akan memberikan solusi untuk mengatasi kesulitan guru dalam mendesain media pembelajaran berorientasi pada pemikiran kritis dan kreatif. Sebelum pelaksanaan kegiatan, mahasiswa telah mendapatkan bekal pengetahuan yang cukup tentang desain media pembelajaran

\section{METODE PELAKSANAAN}

Pelaksanaan kegiatan ini dilakukan dengan mengadopsi langkah - langkah action research yang terdiri dari 4 (empat) tahapan yaitu : persiapan, tindakan, pendampingan dan post kegiatan.

Persiapan meliputi :

a. Persiapan administrasi

Pelaksanaan ini dimulai dari penyusunan program pelatihan. Persyaratan bagi mitra adalah dengan bersedia hadir pelatihan sampai selesai.

b. Persiapan waktu

1) Program Pengabdian kepada Masyarakat ini berjalan selama 6 (enam) bulan yang dilakukan setiap hari Jum'at dan Sabtu.

2) 1 Jenis Pelatihan akan dijalankan selama 1 bulan dengan jumlah tatap muka sebanyak $4 x$

3) 1 pertemuan berlangsung selama 2 jam

c. Persiapan Pengetahuan dan Keterampilan

1) Pelatihan desain bahan ajar yang menarik akan dibawakan oleh Faudunasokhi Telaumbanua, SE, MM

2) Pelatihan membuat video ajar akan dibawakan oleh anggota pengusul 3 (Siti Aisyah, S.Pd, M.Si)

3) Pelatihan membuat evaluasi pembelajaran online akan dibawakan oleh Yusmar Ali, SE, M.Si

d. Persiapan sarana dan prasarana

1) Ketua dan Anggota I menyediakan slide power point

2) Anggota II menyediakan video pelaksanaan

3) Mahasiswa akan menyediakan/menggandakan modul

4) Bahan dan peralatan akan disediakan oleh tim pengusul

Tindakan dan Pendampingan meliputi :

Metode Pelaksanaan Pelatihan Desain Bahan Ajar 


\section{Journal of Social Responsibility Projects by Higher Education Forum}

Vol 2, No 2, November 2021, Page 62-67

ISSN 2723-1674 (Media Online)

Terdapat beberapa langkah yang dilakukan untuk pelatihan bahan ajar yaitu :

a. Dilakukan sosialisasi/pemahaman tentang bahan ajar serta materi ajar yang dilakukan 5 hari sebelum pelaksanaan pelatihan, dengan mengundang narasumber dari luar (Ruri Aditya Sari, M.Sc)

b. Dilakukan pelatihan desain bahan ajar dengan metode ceramah dan praktek sebanyak $4 \mathrm{x}$ pertemuan

c. Pada pertemuan I: pengenalan icon - icon pada power point dan melatih membuat slide standar. Selanjutnya memberikan tugas slide ajar.

d. Pertemuan II : pengenalan icon microsoftword dan melatih membuat modul

e. Pertemuan III - IV : membuat slide dan konten bahan ajar

\section{Metode Pelaksanaan Pelatihan Pembuatan Video Ajar}

Terdapat beberapa langkah yang dilakukan untuk pelatihan yaitu :

a. Dilakukan sosialisasi/pemahaman tentang jenis - jenis video ajar yang dilakukan 2 hari sebelum pelaksanaan pelatihan

b. Dilakukan pelatihan membuat video ajar, dilakukan dengan cara ceramah dan praktek sebanyak $4 \mathrm{x}$ pertemuan

c. Pada pertemuan I : pengenalan video dan praktek membuat video menggunakan 2 aplikasi. Selanjutnya memberikan tugas demo setiap peserta.

d. Pertemuan II : pengenalan zoom dan praktek penggunaan zoom.

e. Pertemuan III - IV : praktek video ajar

\section{Metode Pelaksanaan Pelatihan Membuat Evaluasi Pembelajaran}

Terdapat beberapa langkah yang dilakukan untuk pelatihan bahan ajar yaitu :

a. Dilakukan sosialisasi/pemahaman tentang aplikasi evaluasi pembelajaran online yang dilakukan 2 hari sebelum pelaksanaan pelatihan

b. Dilakukan pelatihan membuat evaluasi pembelajaran online dengan metode ceramah dan praktek sebanyak $4 \mathrm{x}$ pertemuan

c. Pada pertemuan I : pengenalan google form dan melatih membuat tes menggunakan google form. Selanjutnya memberikan tugas.

d. Pertemuan II : pelatihan membuat kuis menggunakan google form

e. Pertemuan III : pelatihan membuat ujian dengan set jadwal dan waktu

f. Pertemuan IV : pelatihan rekap dan koreksi jawaban ujian dari google form

Monitoring dan evaluasi dilakukan oleh tim Pengabdian kepada Masyarakat Kompetitif dengan cara memastikan semua iptek dikuasai dan dipahami oleh peserta pelatihan yaitu guru-guru, evaluasi dilakukan setiap 2x yaitu bulan ke-1 dan bulan ke-3 setelah program selesai untuk memastikan kegiatan tetap berjalan dan kreativitas peserta bertambah dan adanya bahan ajar/video yang dihasilkan oleh peserta dan melakukan post kegiatan yaitu menilai capaian evaluasi pembelajaran.

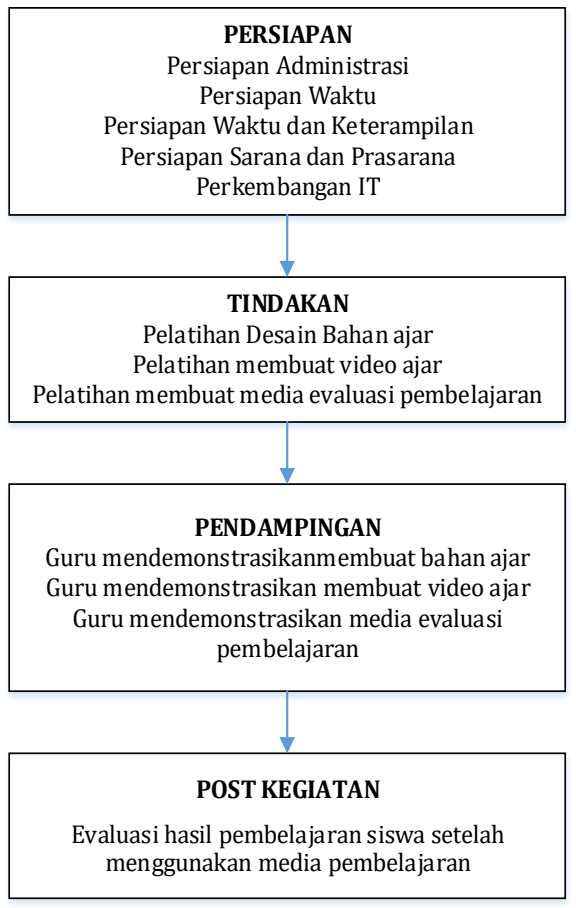

Gambar 1. Tahapan Pelaksanaan Kegiatan 


\section{HASIL DAN PEMBAHASAN}

Hasil dari kegiatan ini adalah sebagai berikut:

\subsection{Pelatihan Desain Bahan Ajar}

Pelatihan Desain Bahan Ajar dilakukan pertama sekali dengan memberikan pemahaman tentang bahan ajar serta materi ajar yang dilakukan 1 minggu ( 5 hari) sebelum pelaksanaan pelatihan, dengan mengundang narasumber dari luar yaitu Ruri Aditya Sari, M.Sc. Berdasarkan hasil dari pretest diperoleh bahwa $70 \%$ guru sudah mengetahui penggunaan powerpoint dan Microsoft word. Namun mereka belum mengetahui bahwa power point dapat dimanfaatkan sebagai salah satu media yang dapat digunakan dalam membuat video ajar. Selain itu, belum pernah ada bahan ajar digital yang disediakan oleh guru untuk mata pelajaran Matematika. Para guru Matematika merasa bahwa sangat susah dalam membuat bahan ajar digital untuk Matematika, karena diperlukan kreatifitas dan pengetahuan yang tinggi dalam membuatnya agar bahan ajar tersebut menarik dan dapat dipahami oleh siswa. Setelah mendapatkan pelatihan desain bahan ajar para Guru dapat membuat bahan ajar mata pelajaran yang mereka ampu. Seperti contoh pada gambar 2, menunjukkan salah satu hasil dari bahan ajar digital Matematika yang dihasilkan oleh Guru.

Selanjutnya, para guru di latih menggunakan Microsoft Word. Setelah diberikan pengenalan tentang icon yang ada di Microsoft word, para guru dapat menghasilkan dokumen yang lebih rapi.

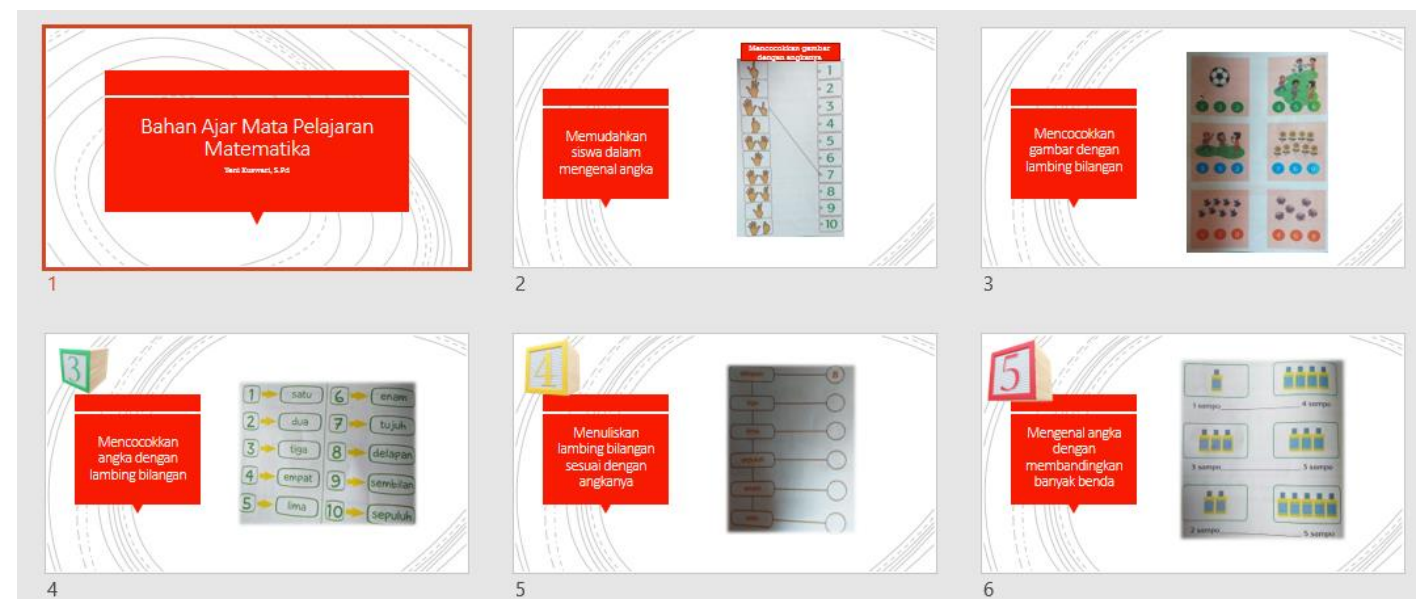

Gambar 2. Salah satu hasil pelatihan Desain Bahan Ajar

\subsection{Pelatihan Pembuatan Video Ajar}

Pelatihan pembuatan video ajar dilakukan pertama sekali dengan memberikan pemahaman tentang jenis - jenis video ajar yang dilakukan 2 hari sebelum pelaksanaan pelatihan. Berdasarkan hasil dari pretest diperoleh bahwa $14 \%$ guru sudah mengetahui pembuatan video ajar dengan menggunakan beberapa software pembuatan video. Namun demikian, para guru yang pernah membuat video ajar sebanyak 20\%. Dengan demikian, pelatihan ini sangat membantu guru dalam menghasilkan video ajar. Gambar 3 merupakan bahan ajar yang diberikan kepada para guru.

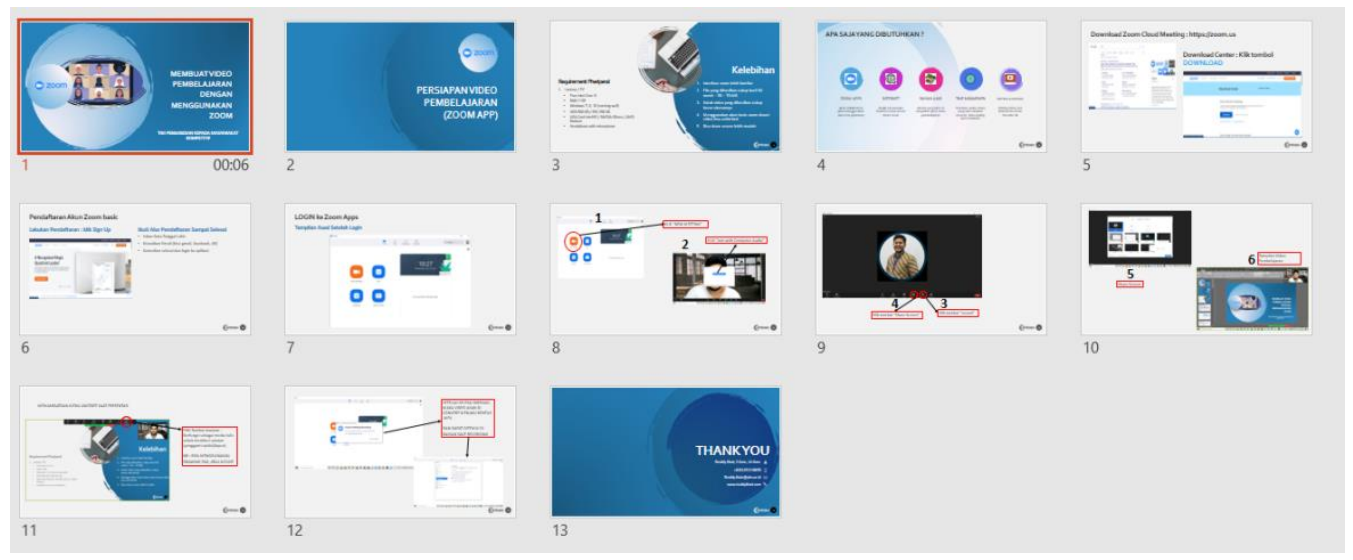

Gambar 3. Bahan Ajar Pelatihan Pembuatan Video Ajar

Setelah diberikan pelatihan pembuatan video ajar, terjadi peningkatan pengetahuan guru tentang penggunaan zoom sebagai salah satu media membuat video ajar. 


\section{Journal of Social Responsibility Projects by Higher Education Forum}

Vol 2, No 2, November 2021, Page 62-67

ISSN 2723-1674 (Media Online)

\subsection{Pelatihan Membuat Evaluasi Pembelajaran}

Pelatihan pembuatan video ajar dilakukan pertama sekali dengan memberikan pemahaman tentang aplikasi evaluasi pembelajaran online yang dilakukan 2 hari sebelum pelaksanaan pelatihan. Berdasarkan hasil pretest menunjukkan bahwa para guru belum mempunyai pengetahuan dalam membuat evaluasi pembelajaran menggunakan google formulir. Selama ini para guru menggunakan google classroom untuk evaluasi pembelajaran.

Setelah pelatihan para guru dapat menghasilkan contoh pertanyaan yang dapat dijadikan evaluasi pembelajaran. Pada gambar 4 menunjukkan contoh google formulir yang dihasilkan oleh guru.
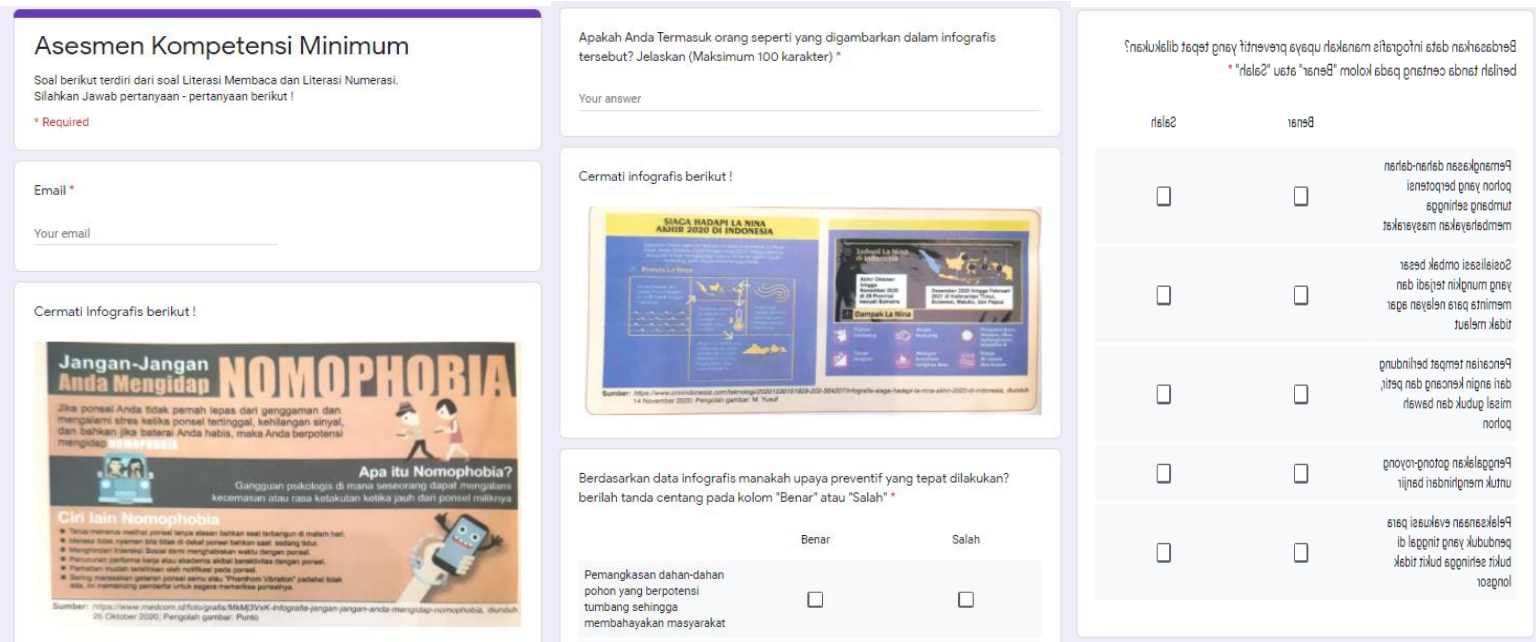

Gambar 4. Salah Satu Hasil Google Formulir yang Dihasilkan oleh Guru

Pengabdian kepada Masyarakat Kompettitif ini memberikan dampak yang sangat baik bagi guru SD An Najwa, hal ini dibuktikan dari hasil post-test. Guru SD An Najwa merasa sangat puas dan senang terhadap kegiatan yang dijalankan, juga sangat puas kepada pemateri-pemateri serta modul ajar yang diberikan oleh tim pengabdian kepada masyarakat. Berdasarkan hasil wawancara dengan ketua Yayasan dan Kepala Sekolah SD An Najwa, mereka menyatakan bahwa terjadi perubahan yang drastis pada guru dalam mengajar selama pandemic ini. Para guru semua memiliki kesibukan dalam membuat bahan ajar dan video ajar. Selan itu, para orang tua juga tidak lagi mengeluh kesulitan mengajarkan anak mereka di rumah. Siswa juga dapat mengulangi pembelajaran walau sudah pulang kerumah, ditambah lagi adanya kebijakan pembatasan (PPKM) yang memaksa proses belajar diadakan secara daring atau secara luring namun dengan jam pertemuan yang dipersingkat. Para guru juga merasa sangat senang sekali adanya kegiatan pengabdian kepada masyarakat kompetitif ini, karena dapat menambah keahlian, menambah ilmu pengetahuan mereka dan mereka menjadi mendapatkan pujian dari orang tua siswa. Gambar 5 merupakan grafik gambaran hasil post-tes setelah pelaksanaan pengabdian kepada masyarakat kompetitif.

Berdasarkan gambar 6, diperoleh bahwa program ini menambah pengetahuan guru sebanyak $85 \%$ dan guru yang kreatif meningkat menjadi 75\%, guru yang terampil mencapai $75 \%$. Selanjutnya, sebanyak $50 \%$ guru menghasilkan bahan ajar, terdapat sebanyak 30\% guru yang melanjutkan menghasilkan video ajar. Melalui video ajar tersebut, guru menjelaskan bahwa tidak ada lagi keluhan orangtua terhadap pelayanan dan fasilitas sekolah selama pandemi. Sebanyak 10\% guru yang menghasilkan google formulir untuk evaluasi pembelajaran.

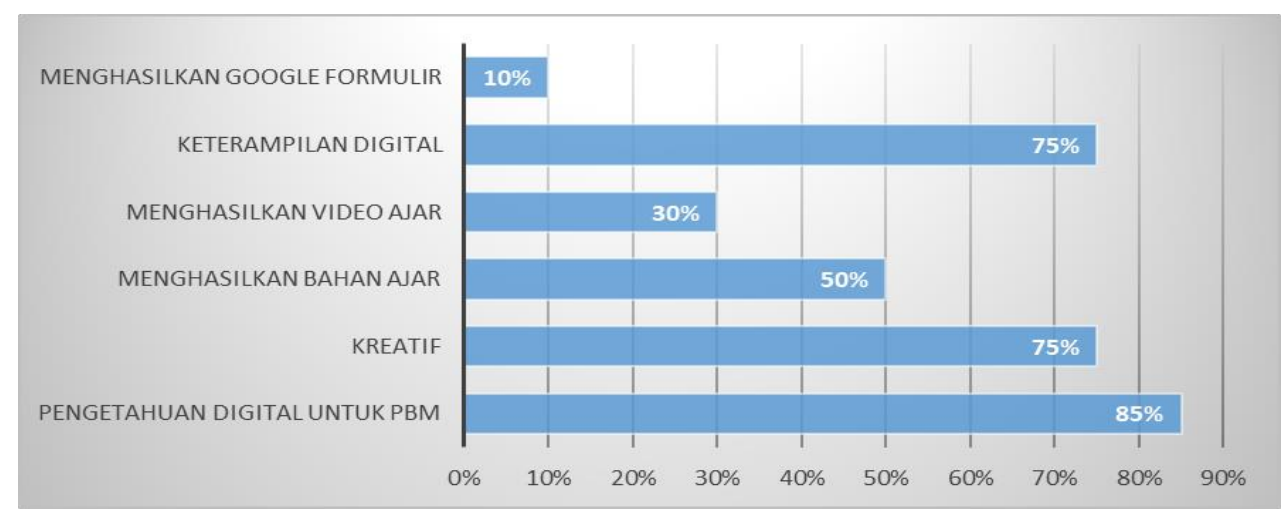

Gambar 5. Hasil Pengabdian kepada Masyarakat terhadap Guru 


\section{Journal of Social Responsibility Projects by Higher Education Forum}

Vol 2, No 2, November 2021, Page 62-67

ISSN 2723-1674 (Media Online)

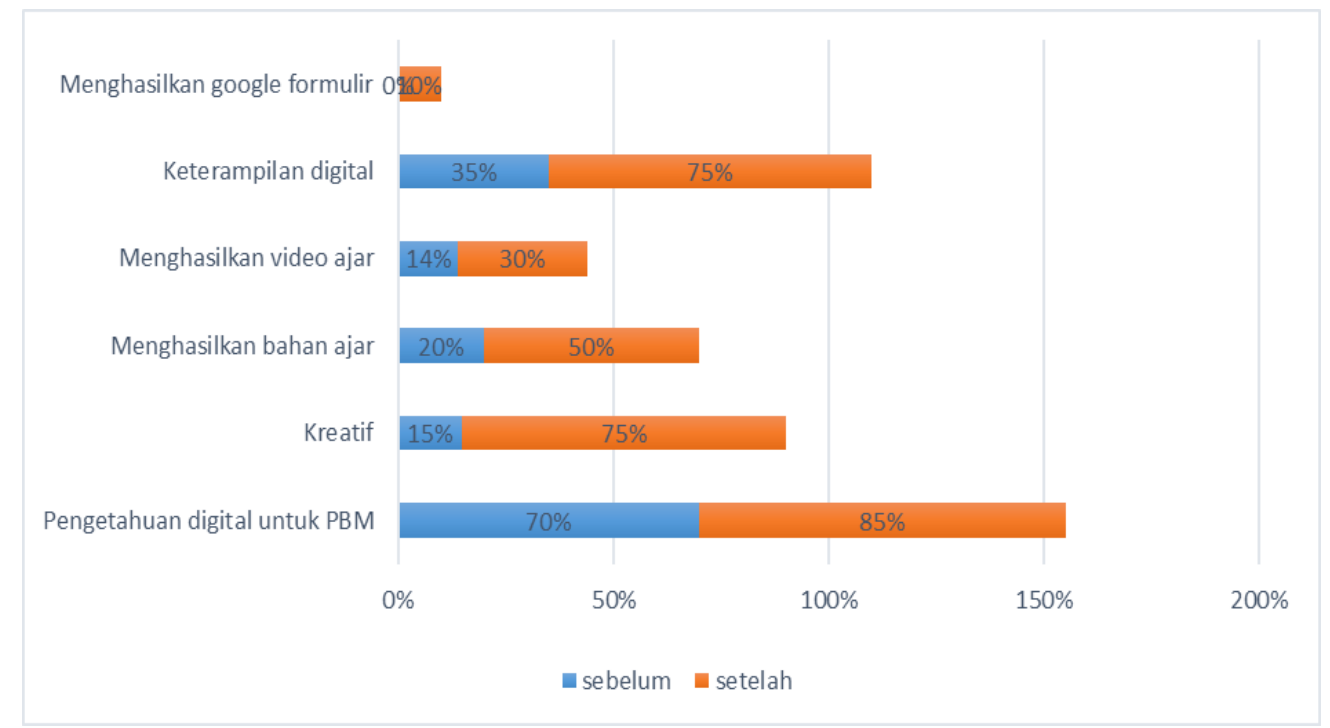

Gambar 6. Perbandingan Capaian Mitra hasil Pengabdian kepada Masyarakat Kompettitif

Hal ini sangat jauh berbeda dengan keadaan sebelum adanya kegiatan Pengabdian kepada Masyarakat Kompettitif. Gambar 6 menunjukkan perbandingan keadaan sebelum adanya Pengabdian kepada Masyarakat Kompettitif. Gambar 7 merupakan gambar suasana pelatihan.
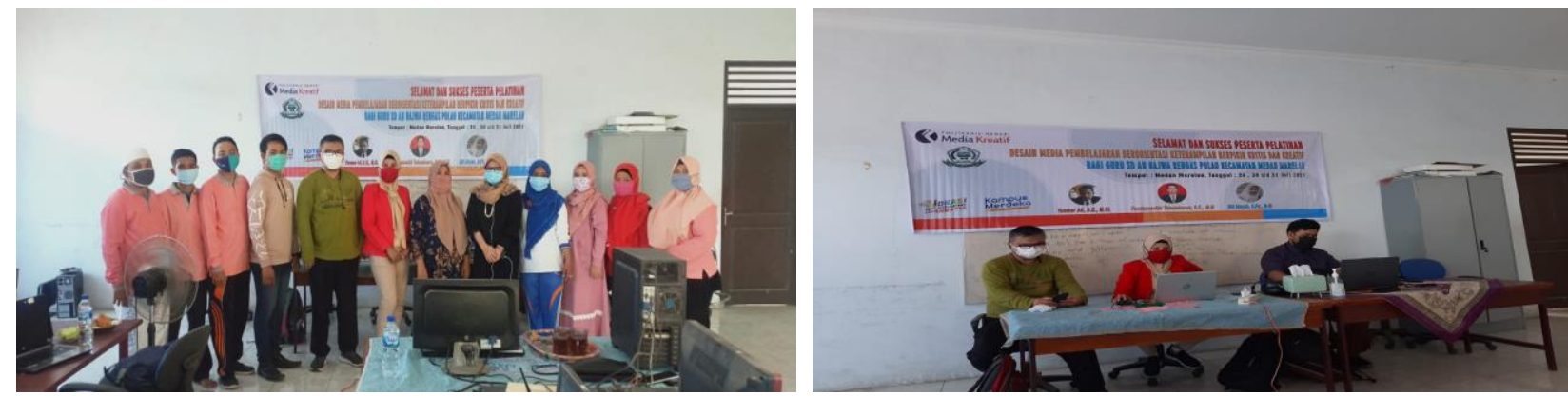

Gambar 7. Berfoto bersama peserta

\section{KESIMPULAN}

Dari program pengabdian kepada masyarakat kompetitif ini memberikan umpan balik yang baik dari mitra, mitra merasa sangat puas dan senang atas pelatihan yang dijalankan. Selain itu, mitra berhasil meningkat ketrampilan dan pengetahuannya dan mitra menjadi kelompok mitra yang lebih kreatif dan inovatif karena mitra menghasilkan bahan ajar dan video pembelajaran sehingga membantu siswa dan orangtua dalam pembelajaran.

\section{DAFTAR PUSTAKA}

Darmadi, H., 2015. Tugas, Peran, Kompetensi dan Tanggungjawab Menjadi Guru Profesional. Jurnal Edukasi, 13(2), pp. 161174

Falahuddin, I., 2014. Pemanfaatan Media dalam Pembelajaran. Jurnal Lingkar Widyaiswara,. 1(4), pp. 104-117.

Putra, S., 2015. Media Pembelajaran Pengenalan Huruf dan Angka di Taman Kanak-Kanak Tunas. Jornal Speed-Sentra Penelitian Engineering dan Edukasi, 7(3), p. 24

Shabir, M. U., 2015. Kedudukan Guru Sebagai Pendidik: (Tugas dan Tanggungjawab, Hak dan Kewajiban dan Kompetensi Guru). Auladuna, 2(2), pp. 221-232.

Tafano, T., 2018. Peran Media Pembelajaran dalam Meningkatkan Minat Belajar Mahasiswa. Jurnal Komunikasi Pendidikan, 2(2), pp. 104-114 